\title{
THE SPILLOVER EFFECTS OF COVID-19 ON HALAL INDUSTRY: AN OVERVIEW AND WAY FORWARD
}

\author{
HARUNA BABATUNDE JAIYEOBA \\ International Institute for Halal Research and Training (INHART), International Islamic University \\ Malaysia, Jalan Gombak, 53100 Kuala Lumpur, Malaysia. \\ *Corresponding author: harunjaiyebab@iium.edu.my
}

(Received: 20 th. Jul. 2020, Accepted: $5^{\text {th }}$ Nov. 2020, Published on-line: $15^{\text {th }}$ Jan. 2021)

\begin{abstract}
This article explores the spillover effects of Covid-19 on halal industry in order to provide a way forward for this industry. Covid-19 pandemic was first discovered in Wuhan city of China before subsequent spread to other countries around the world. To minimise the loss of life and health, governments and global leaders have initiated a series of measures, such as national emergency lockdown, movement restriction (Movement Control Order: MCO), social distancing, suspension of public gatherings beyond a certain number, etc. Albeit essential, these measures have resulted in a major economic crisis with devastating effects on businesses and industries, including halal industry. Against this backdrop, this article, therefore, intends to expose relevant parties in halal industry to the effects of Covid-19 pandemic to better initiate appropriate mechanisms to stabilise this industry and place it on its earlier projected growth trajectory. To achieve its aim, the researcher draws on the real-world observations and relevant publications in this area to discuss the spillover effects of Covid-19 on halal industry with specific focus on three sectors, namely halal food, cosmetics and pharmaceuticals, and Muslim friendly travel. Having discussed the spillover effects of Covid-19 on halal food, cosmetics and pharmaceuticals, and Muslim friendly travel, the way forward and the implications for the halal industry are offered.
\end{abstract}

KEYWORDS: Halal industry; Halal food; Cosmetics and pharmaceuticals; Muslim friendly travel;

Covid-19

\section{INTRODUCTION}

The discovery of Covid-19 pandemic - a highly infectious disease caused by novel coronavirus - in Wuhan city of China and subsequent spread to various other countries have led to substantial disruption in the global economic activities with respect to reduction in production, travel, and trade. The unexpected transformation of this pandemic to unprecedented economic shock has been likened to what economists call a "black swan" - a rare and unanticipated event with dire consequences, (Taleb, 2010). To minimize the loss of human lives and reduce the burden on countries' health care systems, governments and global leaders have initiated series of 
measures, albeit essential, to curtail and prevent the widespread of this contagion, (Fetzer et al., 2020; Nicola et al., 2020). While the measures, such as national emergency lockdown, movement restriction (Movement Control Order (MCO), social distancing, suspension of public gatherings beyond a certain number, etc. instigated by governments are urgent priorities towards minimising loss of life and health; these actions to prevent the further spread of this pandemic have resulted in major economic crisis that will burden businesses and industries for years to come, (Sohrabi et al., 2020), and halal industry is not entirely immune to these economic challenges.

The fear and uncertainty surrounding the spillover effect of Covid-19 as well as post-Covid19 business environment have mandated halal industry's players to deeply understand the effect of this pandemic in order to initiate appropriate mechanisms to stabilize this industry and place it on its earlier projected growth trajectory. Already, the International Monetary Fund (IMF) has projected huge uncertainty about 2020 growth prospects and that the impact of coronavirus will be severe and unprecedented. In addition, the IMF has also downgraded its earlier 2020 growth projection for the global economy, since such estimation has been thrown into serious doubt by the Covid-19 pandemic. As if that were not bad enough, the latest analysis of the International Air Transportation Association (IATA) has shown that COVID-19 pandemic could result in a $\$ 314$ billion drop in the revenue of the travel industry in this year, representing a 55\% decline in the industry' revenue compared to 2019. Yet, the international Labour Organization has estimated global unemployment to be 24.7 million or more as a result of this pandemic.

Furthermore, the effect of Covid-19 has also been felt by the tourism industry as travellers across the world are severely curtailed and prevented from moving around the world. Like never before, several flights and hotel bookings were cancelled; also, many local and international events worth billions of dollars were also cancelled. Similarly, there has been significant reduction in the flow of goods through global halal supply chains given that the leading countries in halal industry as well as others are forced to order emergency closure of major factories to prevent the spread of this pandemic, (Ozili \& Arun, 2020). Besides the supply shock, another major worry is the rising risks in consumers' income and employment that can weaken consumers' economic stability and sentiment, thereby limiting the growth of sectors in the economy. The detrimental effect of weakening economic sentiment, as a result of spillover effect of Covid-19, in disheartening aggregate demand and worsening economic downturns are well captured in the canonical theories of economic demand and the psychology of markets, (Fetzer et al., 2020).

While governments around the world must be commended for their brave actions in setting up task force to ensure that what is primarily known as a medical crisis does not turn into a broader crisis, (Abdullah, 2020), such actions have exposed the weaknesses in supply chains of nations around the world, including major players in halal industry. According to the DinarStandard's (2019) report on the state of the global Islamic economy, the 15 leading countries in halal industry based on Global Islamic Economy Indicator (GIEI) scores are Malaysia, UAE, Bahrain, Saudi Arabia, Indonesia, Oman, Jordan, Pakistan, Kuwait, Qatar, Brunei, Sudan, Turkey, Iran, and Bangladesh, in that order. Among several others that are known when talking about halal industry matters, the above countries have been identified based on the GIEI scores as leaders in global halal food, cosmetics and pharmaceuticals, modest fashion, Muslim friendly travel, media and recreation, and Islamic banking and finance. Undoubtedly, the impact of Covid-19 has been well felt by most of these countries as most of them have reported more than 100,000 cases of Covid-19 as at 22nd October, 2020 as reported by Worldometers 
(available at www.worldometers.info/coronavirus/) while writing this article - see below Figure 1. The development which has caused them to witness waves of national emergency lockdown and movement restrictions, except for companies involved in essential services.

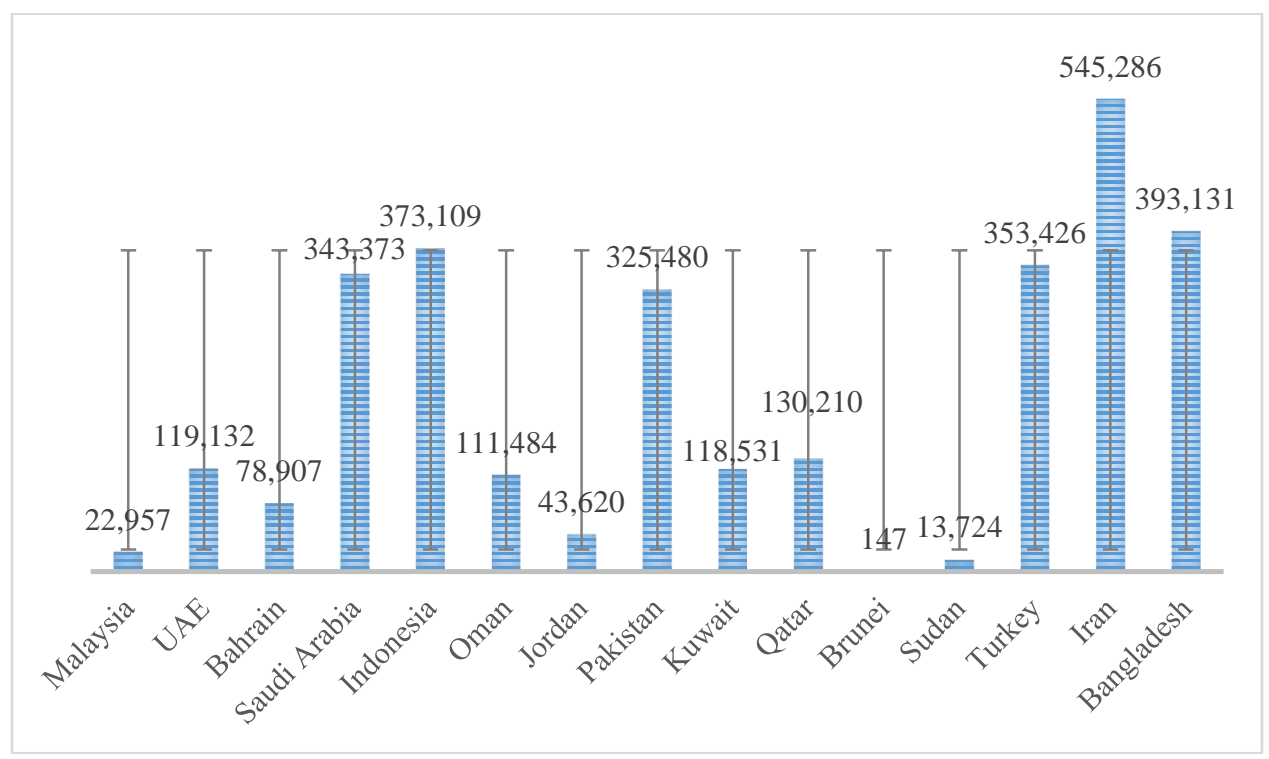

Fig. 1: Reported Cases of Covid-19 in halal industry leading countries. Source: Worldometers

Certainly, the decisions to lockdown and restrict movement have had economic consequences on halal industry, as felt by other industries. While the immediate impact of these actions will be related to production and income losses, prolonged shutdowns could lead to business failures and layoffs, and reductions in investment, consumer spending, and business spending. As such, pointing out the spillover effect of this pandemic on the halal industry by elaborating on how it has impacted halal food, cosmetics and pharmaceuticals, and Muslim friendly travel will help major players in this industry to better know how best to manage it. Although there is a myriad of literature on the impact of crises on businesses, (Fidrmuc \& Korhonen, 2010; Musson \& Rousselière, 2019), article on the spillover effects of Covid-19 on halal industry as discussed in this article is rare. Notwithstanding the importance of this article to the halal mainstream players, this research is set out to benefit researchers, academicians, learners, and contribute to the body of knowledge in this area.

Following the above wide array of introductory discussion, the rest of this article is structured into four sections. Section two briefly elaborates on the rationale and approach for this article. Section three covers the overview of spillover effects of Covid-19 on the halal industry with specific emphasis on the three sectors, namely halal food, cosmetics and pharmaceuticals, and Muslim friendly travel. Section four covers the way forward and implications for the halal industry. The final section - section five - concludes this article and offers recommendations for future studies. 


\section{RATIONALE AND APPROACH FOR THIS ARTICLE}

There is no doubt that the spillover effect of Covid-19 has had some devastating damage to various sectors of the world economy and indeed, those in the halal industry. As reiterated earlier, the pandemic has resulted into reduction in production and income losses, business failures and layoffs, and reductions in investment, consumer spending, and business spending; also, the price of oil was at a time fell to a point that buyers were figuratively being begged to purchase, unemployment rate spiked, stock markets became jittery, business and consumers were in lockdown for several months, et cetera. However, as countries are now transiting out of lockdown towards some form of new normal; this article takes a closer look at the spillover effect of Covid-19 on the halal industry. This is because timely understanding of the spillover effects of Covid-19 on the halal industry is key to initiate appropriate measures by the halal major players and certification bodies to stabilise this industry. With respect to the research approach adopted in conducting this research, the researcher has mainly drawn on the real-world observations and relevant publications to offer the first insight into how the global spread of the novel coronavirus has affected halal food, halal cosmetics and pharmaceuticals, and Muslim friendly travel in a single article.

\section{THE SPILLOVER EFFECTS OF COVID-19 ON THE HALAL INDUSTRY: AN OVERVIEW}

To start with, the word 'halal' represents an Arabic word that means permissible, lawful, or legal based on Islamic law (Syari'ah), and it covers both intangible and tangible products that are perceived to be acceptable to Muslims to consume or use. Halal products encompass halal food, cosmetics and pharmaceuticals, Muslim friendly travel, modest fashion, media and recreation, and Islamic banking and finance. In addition to other basic tenets of Syari'ah, the delivery, processing, transporting, and storing of halal products must also meet acceptable levels of hygiene, cleanliness, and be safe to consumed or used, (Jaiyeoba, et al., 2020). Thus, halal industry is a renowned industry that covers businesses which operate in accordance with the Syari'ah principles and fulfilled certification requirements of halal certifiers, such as Department of Islamic Development Malaysia (JAKIM). While there is vast amount of extant literature on the impact of crises on businesses, studies on the spillover effects of Covid-19 on the halal industry are rare and as such, this section focuses on the spillover effects of Covid-19 on the halal industry.

According to Cortez and Johnston (2020), the effects of current Covid-19 and other crises on businesses are disastrous, and the decline in sales could provoke intra-organizational and interorganizational tension. Cortez and Johnston note that crises that can have significant effect on businesses include natural disasters, such as hurricanes and earthquakes; health epidemics, such as the first SARS outbreak in 2003, H1N1 influenza pandemic in 2009, MERS coronavirus in 2011, and Ebola which broke out in some countries in Africa in 2014; technological disasters, such as the Y2K computer bug; financial crises; and firm and government-level crises, such as union strikes. With this evidence, we can conclude that there have been as many crises in history as wars, but businesses and people equally find it really hard to cope with them when they descend on them. While Covid-19 and other forms crises are abrupt, the unprecedented global scope and biological hazard of Covid-19 makes this crisis unique as it inflicts an uncertain shock 
on human beings at different functions and hierarchies, (Hiscott et al., 2020; Mora Cortez \& Johnston, 2020).

Whether pestilence, financial, or other forms of crises; the impacts of crises on businesses are not the same across business segmentation. For example, Chowdhury (2016) reiterates that small businesses with lower product diversification base as well as with little option for downsizing are largely affected compared with large companies with such capacities irrespective of trade dependency. In addition, credit crunch faced by the small businesses deemed less credible, but are relatively more credit dependent than large businesses; this invigorates the impacts of crises on small businesses than large businesses. Similar to the above small and large businesses analogy, different sectors (halal food, cosmetics and pharmaceuticals, modest fashion, Muslim friendly travel, media and recreation, and Islamic banking and finance) in halal industry are expected to be affected differently by the impact of Covid-19. Hence, the researcher now turns to the spillover effects of Covid-19 on halal industry; here, the focus is on three sectors - halal food, cosmetics and pharmaceuticals, and Muslim friendly travel.

\section{A. The Spillover Effects of Covid-19 on Halal Food}

Halal food comprises various online food chains and offline food chains with focus on foods and beverages allowed under Islamic dietary guidelines. This sector covers halal certified or halal ready companies that are working in processing raw food materials, packaging, and distribution, including the prepared and packaged foods and beverages, (Wibowo et al., 2020). Although the spillover effect of Covid-19 outbreak on this sector is not as bad as sector like Muslim friendly travel; however, governments actions, such as national emergency lockdown, movement restrictions, social distancing, suspension of public gatherings beyond certain number, etc. to curtail the spread of the virus as well as basic aversion behaviour of workers to work during the movement restrictions have reduced the potential of this sector.

The restrictions imposed have reportedly had a profound effect on halal food, since some restaurants and manufacturing companies have to close seating areas or completely close down, which eventually forced on the go consumers who prefer ready to eat foods to eat from home. Besides, the supply chain and transportation of halal food products and raw materials were being delayed and consequently creating food safety concerns or halting halal foods production, since major halal food producing and exporting countries have been affected by Covid-19. Furthermore, fewer workers are also allowed to work together to harvest fruits and vegetables due to social distancing and as such, many plants are reportedly working in a safe mode, which limits the production capacity. Similarly, travel restrictions have led to labour shortage, particularly for the countries or halal certified companies that depend on seasonal workers from other countries in their production of halal foods. Moreover, this pandemic has created shortages of ingredients and raw materials, especially for those imported from overseas, due to border closures to reduce the spread of the virus.

In addition to the supply side, the spillover effect of Covid-19 on employment can also reduce the potential of halal food. While this sector has witnessed large demand due to its commitment to halal standard, which required stringent compliance with guidelines and procedures stipulated by certification bodies (e.g. JAKIM) on halal principles and wholesomeness (including cleanliness and hygiene) in the production of halal foods; loss of income, or reduction of income, or uncertainty regarding the job prospect can shrink the consumption pattern, and may thereby decline sale as well as production. This is particularly true 
given the experience of the 2007/2008 global financial crisis. Equally, the fear of contagion and social distancing rule can translate to aversion to visit halal certified restaurants, halal food markets, or outlets. Also, the effect of border closures on seasonal workers movement and the delay in delivery of halal food products or ingredients might have adverse effects on halal food production and eventually result in inflation - increase in prices of halal foods. Likewise, new standard operating procedures that are now being implemented in various halal companies to ensure acceptable health standards in halal food factories may slow down the production of halal foods, causing prices to increase and lower sales.

\section{B. The Spillover Effects of Covid-19 on Halal Cosmetics and Pharmaceuticals}

Halal cosmetics and pharmaceuticals in halal industry consist of cosmetic and pharmaceutical products allowed to be used or consumed if produced based on the established halal standard guidelines by the halal certification authorities. On the one hand, halal cosmetic products are produced in accordance with the halal system using halal ingredients, and are used as either leave-on or rinse-off purposely for cleansing, beautifying, protecting, or changing body appearance, (Sugibayashi et al., 2019). Halal pharmaceutical products, on the other hand, are medicinal products, dosage forms, or drug products produced from permissible sources and follow the commandments of Syari'ah in preparation, manufacturing, and extraction, (Saha et al., 2019). Notably, halal cosmetic and pharmaceutical products must not be only freed from haram ingredients, they should be wholesome and must not be contaminated with prohibited elements.

As seen in halal food, halal cosmetics and pharmaceuticals have also been affected by the spillover effects of Covid-19. Focusing on the halal cosmetics, the growth enjoined by the cosmetics market before the Covid-19 due to the growing awareness among Muslim consumers, improvements in the halal lifestyle, rising disposable income coupled with the growth in concern related to appearance, and the growing Muslim population has been battered by the recent outbreak of Covid-19. As such, the forecasted growth for the halal cosmetics needs to be relook at, since almost all segments - make-up, skincare, haircare, toiletries and perfumes, and oral cosmetics - have been affected by the movement restrictions, labour shortage, social distancing, cancellation of modest fashion shows, and aversion behaviours of workers to go to work during the outbreak. Following the emergence of Covid-9 and subsequent lockdown of nations to prevent the spread of the virus, halal cosmetic products' sales have shown declining due to low demands because of sit at home order, cancellation of modest fashion shows, and shorting down of cosmetic factories and numerous offline cosmetic stores due to their exclusion from essential services; though there were increased demands for toiletries among others. As a result of the lockdown situation, many halal cosmetic stores have had to cut down the workforce or implement work from home, leading to reduction in the rate of production.

Meanwhile, halal pharmaceuticals are not an exception to the spillover effect of Covid19. Although halal pharmaceutical companies are most favoured and valuable at the current period of health crisis with respect to government policies, support, etc. they are also faced with tough challenges with respect to the conduct of their activities, especially due to the closure of borders by countries to curtail the spread of Covid-19. With renewed efforts to discover vaccines and medications for the newly emerged Covid-19, several other ongoing and planned clinical trials for other diseases were getting postponed and could result in the delay in the development of new medicines for other diseases. Also, halal pharmaceutical companies that sourced their 
Active Pharmaceutical Ingredients (API) or generic drugs from other countries, such as China and India, have got their business operations disrupted by the advent of Covid-19. In other words, their inability to import the required raw materials as well as ancillary supplies have slowed down the manufacturing activity, which in turn will lead to scarcity of essential medicines and lower production outputs and sales, since many of which were forced to operate at low capacity due to the disruptions to supply chains as a result of Covid-19 pandemic and social distancing government directive.

Also, there is an upsurge in the use of digital channels to interact with healthcare professionals as people with underlying medical conditions and older adults, who are at increased risk for severe illness if contracted with Covid-19, are afraid to have face to face contact with health care professionals, couple with the pressure to reduce the number of people admitted into the hospitals. Even those that are active in practicing Just-in-Time (JIT) (an inventory management strategy that aligns raw-material orders from suppliers directly with production schedules) have had to rethink and considering shifting to another inventory management strategy by maintaining inventories for longer duration, which may affect the inventory cycles due to the increased in buffer capacity. Similarly, there are inability of health care professionals in halal industry to move around the world for training and development purposes, while several major events and conferences organised for them were cancelled or postponed due to Covid-19.

\section{The Spillover Effects of Covid-19 on Muslim Friendly Travel}

Muslim friendly travel focuses on tour or travelling packages and destinations designed in such that address and cater for the Muslim needs, and strictly adheres to Syari'ah principles, since Muslim tourists are inclined to honour and practice various religious beliefs, preferences, habits, and behaviours when away from home for certain permissible purpose, (Boğan \& Sarış1k, 2019; Oktadiana et al., 2016). Muslim friendly tourism covers Muslim friendly hotels, transportation, attractions, restaurants, airports, airlines, cruises, geopark, and spas and wellness, (Henderson, 2016; Liu et al., 2018). Muslim friendly travel represents one of the biggest niche markets in the global tourism and has been continually growing due to several factors, such as growing Muslim population, increasing access to travel information, growing middle class and disposable income, availability of Muslim-friendly travel services and facilities, and religious and business travels, (Boğan \& Sarışı1, 2019).

While Muslim friendly travel represents an important source of income in most countries around the world as well as being one of the fastest growing segments in the global tourism, the spillover effect of Covid-19 is being felt throughout the entire Muslim friendly tourism ecosystem. To prevent the spread of Covid-19, the measures put in place have led to significant reduction in the travelers travelling to other countries. According to the Organisation for Economic Co-operation and Development's (2020), report on tourism policy responses, international tourism will decline by $60 \%$ in 2020, but if the recovery is delayed until December, declining may rise to 80 percent. As a result of Covid-19, several proposed travelling was cancelled, many workers were laid off, or faced with pay cuts, or sent to unpaid leave due to the spillover effect of Covid-19.

The social distancing and movement restriction measures have instigated the closing down of nonessential businesses and several places of visit, like geopark, attractions, hotels, and spas and wellness, since they were not recognised to be part of essential businesses and services. 
The increasing cases of COVID-19 have also informed many Muslim travelers to cancel their trips as well as hotel room reservations. In Malaysia alone, about 170,084 hotel room bookings were cancelled between $11^{\text {th }}$ January 2020 and $16^{\text {th }}$ March, 2020 because of the outbreak of Covid-19, resulting into loss of RM 68,190,364 revenue, according to Foo et al., (2020). Similarly, many workers were laid off, or faced with pay cuts, or sent to unpaid leave due to the spillover effect of Covid-19.

\section{THE WAY FORWARD AND IMPLICATIONS FOR HALAL INDUSTRY}

The real-world observations and review of existing publications suggest that there is a need for halal industry to reconceptualise in the new normal to achieve its earlier projected growth. Rather than relying on the traditional approach of doing business, a broader and more systematic approach is needed at this time and beyond. In other words, a goal-orientated and sustainable thinking is required to build on the successes recorded before the emergence of Covid-19. As such, halal certification bodies must come together to rethink how to stay focus on the desired results that can help this industry to grow even beyond the initial projected growth. Although halal industry has been reported to worth billions of US dollars, but when viewed critically to know how much successes can be recorded by leveraging on onshore and Muslim majority countries, the pandemic reveals a lot. As such, leading countries in halal industry as well as other Muslim majority countries should wake up to this reality by working together and playing enormous role to station this industry to achieve its earlier projected growth, since relying heavily on external trade is a risk to minimise. Ever than before, halal companies must act fast in responding and adapting to new customers' norm using appropriate business model, rethink what drives brand loyalty, prepare a more robust business continuity plan with more emphasis on the recovery options should similar crisis occur in the future, be better informed on how best to manage their businesses as well as the strategy and brand issues that will define their future, and always observe recommended universally precautionary measures, including practising high personal hygiene.

In addition to various government supports to support halal industry during this critical period, Islamic financial institutions are also in a unique position to play a vital role in sustaining halal businesses. To alleviate the spillover effect of Covid-19, Islamic financial institutions need to enhance access to financing for halal businesses in their trade financing, working capital needs, etc. It is important to stress here that almost any financial relief extended to halal businesses that are currently struggling or where business activities were disrupted by the COVID-19 pandemic would be welcome and help in sustaining such businesses. As such, quick response to high volume of requests from halal businesses will, in tandem, increase the reputation, value, and/or define the future brand of Islamic financial institutions beyond this period. In addition, providing needed support to halal businesses will require Islamic financial institutions to lead a coherent and extensive response to halal businesses by deploying the tools they have developed since the 2007/2008 financial crisis.

Furthermore, business closures and consumer lockdowns to prevent the spread of Covid-19 had seen significant reduction in the brick and mortar sales, creating an uptick in the use of ecommerce and online activities to create more sales. Thus, digital transformation has become more important than ever before and halal businesses must act fast to move towards this direction. In other words, having cross channel marketing strategies is not an option at this time, 
but must be rolled out as soon as possible. To avoid the risk of rushing into an online platform to create customer experience, halal businesses must do that in more coordinated and through the correct ways, such as how direct-to-consumer brands have done it, and must take responsibility for end-to-end experience. Moreover, halal businesses also need to ensure marketing transitioned from mass to personalised, since they now have to understand the contextual environment their customers are currently in. Similarly, business activities and payment should be simplified using technology because businesses are expected to grow if customers can conveniently and easily pay for products or services without stress. Therefore, a special group of brand loyalists who will have confidence in halal brand will be created if halal companies can effectively engage with customers during this difficult moment.

For the halal certification bodies in Malaysia and around the world, significant amount of resources and time must be invested to raise the awareness of the benefits or the importance of securing halal certification among the businesses, particularly since Good Hygienic Practices (GHP) and Good Manufacturing Practices (GMP), which are crucial in the halal certification process, have become important point of discussion nowadays. In this case, efforts should be made in explaining how halal certification could improve internal operations, customer confidence, and add value to the businesses, such as increase in sales, as a direct result of halal verification. Before now, much have by said and documented about the harmonisation of halal certification authorities; however, the current situation is a call to the players in this industry to urgently revisit this issue, especially in ensuring the acceptance of products certified in a particular in overseas markets. Hence, this will help to prove that halal certification is not only a tool to deliver internal business improvement or to meet regulatory compliance, but something that will positively impact the revenue. Ultimately, a joint efforts of halal certification bodies in Malaysia and around the world will help to stabilise this industry and place it on its earlier projected growth trajectory.

\section{CONCLUSION}

This article provides an overview of Covid-19's spillover effects on the halal industry to enable the players in this industry to better understand and initiate appropriate strategies to position halal industry to its earlier projected growth. The outbreak of Covid-19 pandemic has triggered global recession in 2020 due to the measures instigated to curtail its spread and minimise its impact on life. Even with the government fast policy response in providing palliative to alleviate the negative effects of this pandemic, many companies have reportedly bankrupted, and many countries have been plunged into a recession. The recession currently experienced by many countries around the world is a reflection of difficult choices the authorities had to make to prioritise human protection above the economy.

Therefore, this article has offered insights into the spillover effects of Covid-19 on halal industry with specific focus on halal food, halal cosmetics and pharmaceuticals, and Muslim friendly travel; similarly, the researcher has elaborated on the way forward and the implications of this article for halal industry. As mentioned, halal companies must act fast in responding and adapting to new customers' norm using appropriate business model, rethink what drives brand loyalty, prepare a more robust business continuity plan with more emphasis on the recovery options should similar crisis occur in the future, be better informed on how best to manage their businesses as well as the strategy and brand issues that will define their future, and always observe recommended universally precautionary measures, including practising high personal 
hygiene. Islamic financial institutions are also in a unique position to play a vital role in sustaining halal businesses. To alleviate the spillover effect of Covid-19, Islamic financial institutions need to enhance access to financing for halal businesses in their trade financing, working capital needs, etc. Furthermore, digital transformation has become more important than ever before and halal businesses must act fast to move towards this direction. Finally, halal certification bodies in Malaysia and around the world, significant amount of resources and time must be invested to raise the awareness of the benefits or the importance of securing halal certification among the businesses.

Based on the discussions offered in this article, it is envisaged that relevant bodies, such as JAKIM, will be guided when making decisions specifically on the halal certified companies or on halal industry in general. While this article has mainly reviewed relevant publications in this area of article, future researchers are encouraged to make use of qualitative data, quantitative data, or both to improve our understanding about the spillover effects of Covid-19 on the halal industry. In addition, such researchers may also conduct cross sectional or longitudinal research when trying to provide more insights into the impact of Covid-19 on the halal industry.

\section{REFERENCES}

[1] Abdullah, N. (2020, March). Covid-19: Time to be innovative. Retrieved May 11, 2020, from https://www.nst.com.my/opinion/letters/2020/03/579346/covid-19-time-beinnovative

[2] Boğan, E., \& Sarışık, M. (2019). Halal tourism: conceptual and practical challenges. Journal of Islamic Marketing, 10(1), 87-96. https://doi.org/10.1108/JIMA-06-2017-0066

[3] Chowdhury, S. R. (2016). Impact of Global Crisis on Small and Medium Enterprises. Global Business Review, 2(2010), 133-149. https://doi.org/10.1177/097215091101200303

[4] Cortez, R. M., \& Johnston, W. J. (2020). The Coronavirus crisis in B2B settings: Crisis uniqueness and managerial implications based on social exchange theory. Industrial Marketing Management, 88, 125-135. https://doi.org/10.1016/j.indmarman.2020.05.004

[5] DinarStandard. (2019). State of the Global Islamic Economy Report. New York. Retrieved from https://www.salaamgateway.com/SGIE19-20

[6] Fetzer, T., Hensel, L., Hermle, J., \& Roth, C. (2020). Coronavirus Perceptions And Economic Anxiety.

[7] Fidrmuc, J., \& Korhonen, I. (2010). The impact of the global financial crisis on business cycles in Asian emerging economies. Journal of Asian Economics, 21(3), 293-303. https://doi.org/10.1016/j.asieco.2009.07.007

[8] Foo, L.-P., Chin, M.-Y., Tan, K.-L., \& Phuah, K.-T. (2020). The impact of COVID-19 on tourism industry in Malaysia. Current Issues in Tourism, 0(0), 1-5. https://doi.org/10.1080/13683500.2020.1777951

[9] Henderson, J. C. (2016). Halal food, certification and halal tourism: Insights from Malaysia and Singapore. Tourism Management Perspectives, 19, 160-164. https://doi.org/10.1016/j.tmp.2015.12.006

[10] Hiscott, J., Alexandridi, M., Muscolini, M., Tassone, E., Palermo, E., Soultsioti, M., \& Zevini, A. (2020). The global impact of the coronavirus pandemic. Cytokine and Growth Factor Reviews, 53(May), 1-9. https://doi.org/10.1016/j.cytogfr.2020.05.010

[11] International Air Transportation Association. (2020). Airlines could lose more than $\$ 300$ 
billion. Retrieved from https://airlines.iata.org/news/airlines-could-lose-more-than-300billion-0

[12] Jaiyeoba, H. B., Abdullah, M. A., \& Dzuljastri, A. R. (2020). Halal certification mark, brand quality, and awareness: Do they influence buying decisions of Nigerian consumers? Journal of Islamic Marketing, In Press. https://doi.org/10.1108/JIMA-072019-0155

[13] Liu, Y.-C., Li, I.-J., Yen, S.-Y., \& Sher, P. J. (2018). What Makes Muslim Friendly Tourism? An Empirical Study on Destination Image, Tourist Attitude and Travel Intention. Advances in Management \& Applied Economics, 8(5), 1792-7552. https://doi.org/http://www.scienpress.com/Upload/AMAE\%2fVol\%208_5_3.pdf

[14] Mora Cortez, R., \& Johnston, W. J. (2020). The Coronavirus crisis in B2B settings: Crisis uniqueness and managerial implications based on social exchange theory. Industrial Marketing Management, 88(May), 125-135. https://doi.org/10.1016/j.indmarman.2020.05.004

[15] Musson, A., \& Rousselière, D. (2019). Identifying the impact of crisis on cooperative capital constraint. A short note on French craftsmen cooperatives. Finance Research Letters, In Press. https://doi.org/10.1016/j.frl.2019.09.005

[16] Nicola, M., Alsafi, Z., Sohrabi, C., Kerwan, A., \& Al-jabir, A. (2020). Title: The SocioEconomic Implications of the Coronavirus and COVID-. International Journal of Surgery. IJS Publishing Group Ltd. https://doi.org/10.1016/j.ijsu.2020.04.018

[17] OECD. (2020). Tourism Policy Responses to the coronavirus (COVID-19). Paris: OECD. Retrieved from https://read.oecd-ilibrary.org/view/?ref=124_1249847uf8nm95se\&Title=Covid-19: Tourism Policy Responses

[18] Oktadiana, H., Pearce, P. L., \& Chon, K. (2016). Muslim travellers' needs: What don't we know? Tourism Management Perspectives, 20, 124-130. https://doi.org/10.1016/j.tmp.2016.08.004

[19] Ozili, P., \& Arun, T. (2020). Spillover of COVID-19: impact on the Global Economy. SSRN Electronic Journal, 1-23. https://doi.org/10.2139/ssrn.3562570

[20] Saha, T., Rifat, T., \& Shimanto, S. (2019). Prospects of Halal Pharmaceuticals. Asian Journal of Ethnopharmacology and Medicinal Foods, 5(2), (17-23.

[21] Sohrabi, C., Alsafi, Z., Neill, N. O., Khan, M., Kerwan, A., Al-, A., ... Agha, R. (2020). World Health Organization declares Global Emergency: A review of the 2019 Novel Coronavirus (COVID-19). International Journal of Surgery, 76, 71-76. https://doi.org/10.1016/j.ijsu.2020.02.034

[22] Sugibayashi, K., Yusuf, E., Todo, H., Dahlizar, S., Sakdiset, P., Arce, F. J., \& See, G. L. (2019). Halal Cosmetics: A Review on Ingredients, Production, and Testing Methods. Cosmetics, 6(37), 1-17.

[23] Taleb, N. N. (2010). The Black Swan: The Impact of the Highly Improbable. New York: Random House.

[24] Wibowo, M. W., Permana, D., Hanafiah, A., Ting, H., \& Sh Ahmad, F. (2020). Halal food credence: do the Malaysian non-Muslim consumers hesitate? Journal of Islamic Marketing, 1759-0833. https://doi.org/10.1108/JIMA-01-2020-0013 